\title{
Effects of Foreign Loans, Interest Rate, and Export on the Foreign Exchange Reserves in Indonesia 2002-2016
}

\author{
Anas Iswanto Anwar ${ }^{\mathrm{a}, *}$, Bayu Pamungkas Djamal ${ }^{\mathrm{a}}$, Sri Undai Nurbayani ${ }^{\mathrm{a}}$ \\ ${ }^{a}$ Faculty of Economics and Business, Universitas Hasanuddin
}

\begin{abstract}
This research aims to analyze the effect of foreign loans, interest rate, and export for the foreign exchange reserves in Indonesia during 2002-2016. This research used secondary data, which tends the time-series published by Bank Indonesia, The Ministry of Trade Republic of Indonesia, Central Agency on Statistics Indonesia in the year 2002-2016. The result of the regression by using ordinary least squares (OLS) method showed that the foreign loans and export take effect positively to the foreign exchange reserves. It indicates that the increase of foreign loans and export could affect the foreign exchange reserves in Indonesia during 2002-2016. Otherwise, the interest rate could not affect the foreign exchange reserves in Indonesia during 2002-2016.
\end{abstract}

Keywords:

foreign exchange reserves, foreign loans, interest rate, export

\section{INTRODUCTION}

Foreign exchange is several foreign exchanges that are used to finance all international trade transactions or trade between countries. Foreign exchange can also be interpreted as wealth in the form of foreign currency owned by a country. Foreign exchange itself consists of foreign exchange, which is the currency that is recognized and accepted by all countries in the world such as US Dollar, Canadian Dollar, Euro (Europe), Pound Sterling (UK), Franc (France), Franc (Switzerland), Deutsche Mark (Germany), Yen (Japanese), gold, and securities that apply in international payments.

Foreign exchange reserves are assets owned by central banks and monetary authorities, usually in different reserve currencies, mostly US dollars, and to a lesser extent Euro, Pounds Sterling and Japanese yen, and used to support obligations such as local currency issued, and various bank reserves held by the central bank, by the government or financial institutions. Development that was initially centered on the agricultural sector was slowly directed towards the industrial sector because it saw many countries benefit from this industrialization sector.

With the start of industrialization in Indonesia, foreign exchange is naturally needed. The source of foreign trade financing is stored in foreign exchange reserves, which are accounted

\footnotetext{
*Author in correspondence,

Email address: aianwar@fe.unhas.ac.id (Anas Iswanto Anwar)
}

ISSN: 2549-3221 (Print) 2549-323X (Online)

DOI: 10.26487 /hebr.v3i2.1942 for by Bank Indonesia, and recorded in Bank Indonesia's balance of payments. The more active we are in industrializing, the more foreign exchange is needed, and the need is intended for consumer goods but is now slowly changing for the fulfillment of capital goods and raw materials. Foreign exchange is also widely used for the construction of industrial projects and projects such as roads, bridges, docks, airstrips, and terminals.

During the period of development of domestic industrialization, of course, the question is the source of our country's foreign exchange reserves. Foreign exchange reserves are certainly a reliable indicator to see the extent to which a country is able to trade and show the country's economy, which is the source of foreign exchange reserves initially is the belief that Indonesia has abundant natural resources and undoubtedly worth trading abroad, and the rest funding can be through foreign assistance either through foreign loans as well as through grants or often called capital outflow.

The foreign exchange used for this development is derived from the foreign exchange from our exports of oil and gas and non-oil and tourism services, and even our foreign exchange earnings are also obtained from foreign loans to be able to carry out the development. In summary, foreign exchange is necessary for a country that is actively developing (?). Asmanto and Suryandari 2008 explained that foreign exchange reserves have an essential role and are an indicator to show the strength and weakness of a country's economic fundamentals. In addition, it is a crucial key for a country to be able to avoid economic and financial crises. The impact of the economic crisis, when 
viewed from the perspective of the balance of payments, is the depletion of the country's foreign exchange reserves.

Foreign exchange reserves become a critical indicator in measuring the development of trade and economy of a country. Several factors that can affect Indonesia's foreign exchange reserves include foreign loans, interest rates, and exports. Foreign loans can be used as a factor that can be utilized to increase the country's foreign exchange reserves.

The use of foreign loans is expected to increase state investment so that it can stimulate the country's economic growth more quickly. One of the burdens of foreign loans can be measured by looking at the proportion of foreign exchange earnings in the current account originating from exports absorbed by all debt services in the form of interest and debt installments (Atmaja 2008). Foreign exchange that enters a country can be in the form of export payments, investments, bilateral assistance, and loans. Mankiw 2000 explained that falling interest rates would cause people to borrow loans in banks and use these loans for investment so that production will increase and exports will also increase. The more trade export activities, the more it will affect the country's foreign exchange reserves.

The condition of Indonesia after the economic crisis showed the depletion of foreign reserves for domestic needs because the foreign export exchange was lower than foreign exchange imports. It is necessary to know the factors that affect foreign exchange reserves in Indonesia, namely foreign loans, interest rates, and exports, to maintain foreign exchange reserves at a safe level.

\section{LITERATURE REVIEW}

The development of the balance of payments theory began with the concept of the trade balance of the classical, which was first represented by Thomas Mun. Thomas Mun, one of the figures of Mercantilist, said that one of the principles of the trade balance is that it must be a surplus so that there is a gold inflow. Thus the country's wealth becomes increased. Mun recommended that international trade should be regulated by emphasizing restrictions on imports and vice versa, encouraging exports.

David Hume denies the above income by stating that the government does not need to regulate international trade. Because automatically with the mechanism of the flow of gold, the international trade balance will be balanced again. The mechanism works because if a country has a trade balance surplus, there will be a gold inflow that will cause the money supply to increase, which in turn will raise prices. The impact is that the value of exports declined and imports rise until the balance of payment returns is reached. The classical economist, driven by Adam Smith, followed David Hume's idea. The balance of payments will automatically reach balance through a market mechanism.

In the 1930s, when the world was hit by a severe crisis marked by falling production and rising unemployment, Keynes appeared to fight the classical schools of thought. Unlike the classics, Keynes does not believe in the existence of market mechanisms. Keynes argued that the balance of payments did not automatically reach a balance but instead needed government intervention. This Keynesian thought, later developed by economists, afterward, focused on a balance of payment theory (Nopirin 1998).

Keynes explained the negative relationship between income (Y) and foreign exchange reserves (R). This is explained by using the concept of marginal propensity to consume (MPC), i.e., if national income rises, it will increase imports by increasing income multiplied by MPC. On the other hand, monetarists explain the positive relationship between income (Y) and foreign exchange reserves $(\mathrm{R})$ through the money market. Another meaningful relationship is between foreign reserves and domestic credit (DC). As expressed by the monetarists, the coefficient on domestic credit is negative, meaning that with an increase in domestic credit, the money supply will increase, resulting in a decrease in the interest rate so that there will be an outflow of foreign exchange resulting in a decrease in foreign exchange reserves. The effect of government expenditure $(\mathrm{G})$ on foreign exchange reserves $(\mathrm{R})$ both Keynes and Monetary shows both positive signs. Changes in the exchange rate have an impact on increasing foreign exchange reserves.

Starting in July 2000, Bank Indonesia changed the concept of recording foreign exchange reserves. Reported foreign exchange reserves only use the concept of the International Reserve and Foreign Currency (IRFCL), which is an international reporting standard (SDDS-IMF). The difference between the number of foreign exchange reserves based on the concept of GFA (Gross Floor Area) with IRFCL occurs due to differences in definition. IRFCL is only a liquid asset that is calculated, as a component of international reserves, and its valuation uses the exchange rate prevailing at the reporting date. In contrast, in the GFA concept, the liquidity level is not distinguished, and the exchange rate is not used at the time of reporting, but the foreign exchange rate as of March 31, 1998.

The IRFCL concept departs from the Special Data Dissemination Standards (SDDS), which is a form of presentation of economic data via the internet using the International Monetary Fund (IMF) data presentation standards. SDDS coverage is the real sector, fiscal sector, financial sector, and external sector. Regarding IRFCL, the structure of the method is divided into international reserves, estimates of scheduled net foreign exchange flows (predetermined short-term net drains), estimates of contingent short-term net drains, and memo items.

The main factor of the source of Indonesia's foreign exchange reserves is the most reliable is the result of exports (international trade) source of income is a substantial increase in foreign exchange reserves. Exports and imports account for $30 \%$ of national income, and this will add to the foreign exchange surplus, which is the government's cash in financing and development.

Foreign loans are a portion of a country's total loans obtained from creditors outside the country. Recipients of foreign loans can be in the form of governments, companies, or individuals. The form of loans can be in the form of money obtained from private banks, governments of other countries, or international financial institutions such as the IMF and world banks. 
Loans are one of the alternatives chosen as a source of financing because of the need to be resolved immediately. In the structure of the State Budget (APBN), foreign loans are intended as development expenditures originating from program loans and project loans. The foreign funds obtained are then used as a source of development funding in various sectors of the country's life.

The current account deficit is often cited in the literature as a significant cause of the swelling of loans from many developing countries. The large current account deficit exceeds the Capital Account (CA) capital account surplus resulting in a balance of payments (BOP) balance of payments deficit, which means that foreign exchange reserves are reduced. If the current account balance is negative each year, the foreign exchange reserves will automatically be exhausted if there are no sources other sources, such as investment capital from abroad.

At the beginning of the development of a country, it is natural that very large funds are needed for investment and economic growth if domestic savings are not enough then the easiest way is to carry out foreign loans. Foreign loans have a positive impact on investment and economic growth in certain situations. Foreign loans will cause problems if the funds are not invested in productive activities that generate high foreign exchange return to cover interest payments (Abadi 2014 have proven that the accumulation of foreign loans that occur due to the increasing need to pay off past debts will negatively impact investment and economic growth after exceeding a certain threshold.

At the level of significant loan accumulations, it will cause low economic growth. This is because, in the long run, the loan will be greater than the debtor's ability to pay, the cost of loan interest is expected to push domestic investment and foreign investment, which ultimately inhibits economic growth (Pattillo 2002). The debt burden is so great (Debt overhang) the hypothesis shows that accumulated loans act as future tax output, discouraging productive private sector investment plans and adjustments on the part of the government.

At least, there are big problems caused by foreign loans (Yustika 2000). Foreign loans do not come in the form of money, but most are in the form of goods or technology. Under these circumstances, the use of foreign loans is inflexible because the product or technology can clearly only be used for certain programs. The mechanism can occur considering the lending procedure is through the selection of proposals containing planned programs, and if it has been approved then the program needs are realized in the form of goods or technology, not money, this is clearly different in consequences if the debt is forgotten in the form of money, because then the user can be more adapted to the real needs that develop in the implementation of the program.

According to the classic view of foreign loans, tax cuts funded by loans encourage consumer spending and reduce national saving. This increase in consumer spending leads to greater aggregate demand and higher income in the short term, but it also causes smaller capital stock and lower-income, so that foreign loans will be higher in the long run (Mankiw 2000).

According to Ricardian's view of government loans, con- sumer spending does not increase overall consumer resources and tax cuts. In the short term, foreign loans increase current income; in the long run, do not change future income or consumption. This view will burden future generations of people Mankiw 2000). The Ricardian, in Ricardian Equivalence (RE) theory, believes that the budget deficit funded by foreign loans will not have any effect on the economy.

This theory originated with David Ricardo's Funding System and put forward again by Barro, so it is often given the name Ricardo-Barro Preposition. This happens because the effects of growth in government spending financed with government loans must be paid by the government in the future with a tax increase, so that people will reduce their current consumption to increase savings, then used to pay tax increases in the future.

Keynesians are Keynesians who argue that the fiscal deficit financed by foreign loans affects the economy. This understanding sees the policy of increasing the expenditure budget financed with foreign loans will have a significant influence on economic growth due to rising aggregate demand as a further effect of capital accumulation. According to the Keynesians, the budget deficit will increase income and welfare, and consumption in the next turn. Interest rates are annual interest payments from a loan, in the form of a percentage of the loan obtained from the amount of interest received each year divided by the number of loans.

The interest rate itself is determined by two forces, namely: the supply of savings and the demand for capital investment (mainly from the business sector). Savings is the difference between income and consumption. Interest basically acts as the main driver so that people are willing to save. The amount of savings will be determined by high and low-interest rates. The higher the interest rate, the higher the community's interest in saving and vice versa. The high or low supply of investment funds is determined by the high and low-interest rates on public savings.

According to Lipsey and Courant 1997 the interest rate is the price paid for a unit of currency borrowed at a particular period. Interest rates can be divided into two, namely nominal interest rates and real interest rates, where the nominal interest rate is the ratio between the amount of money repaid with the amount of money borrowed. While the real interest rate places more emphasis on the ratio of the purchasing power of money paid back to the purchasing power of money borrowed. Real interest rates are the difference between the nominal interest rate and the inflation rate. According to Samuelson and Nordhaus 1997, interest rates are payments made on the use of a sum of money.

According to Nopirin 1998, the function of the interest rate in the economy is the allocation of factors of production to produce goods and services used now and in the future. There are two types of factors that determine the value of interest rates, namely, internal and external factors. Internal factors include national income, money supply, and inflation, while external factors are foreign interest rates and the expected rate of change in foreign exchange rates. Prasetiantono 2000 regarding interest rates are: if interest rates are high, automatically people will 
prefer to save their funds in the bank because they can expect a favorable return, and in this position, people's demand to hold cash becomes lower because they are busy allocating it into the form of a banking portfolio (deposits and savings).

As the money supply decreases, spending arousal declines, and prices of general goods and services will tend to stagnate, or there will be no inflationary impetus. Conversely, if interest rates are low, people will not be interested anymore to keep their money in banks. Some aspects that can explain the phenomenon of high-interest rates in Indonesia are high-interest rates related to the performance of the banking sector that functions as an intermediary institution, people's habits to get along and take advantage of various bank services is relatively still not high enough, and it is challenging to reduce rates banking interest if inflation rates are always high Prasetiantono 2000.

Export is one of the economic sectors that play an important role and through a market expansion the industrial sector will encourage other industrial sectors, and the economy (Meier 1995) in conclusion exports are a source of foreign exchange plus market expansion for the production of domestic goods and expansion of labor (Muhammad 2006).

There is a need for policy considerations that lead to the expansion of exports, especially since this component is our source of foreign exchange $70 \%$, which encourages export behavior initially is a country's commitment to be open to international trade. In the theory of Thomas Mun (Classical economic figure) states that international trade will benefit a country's balance of payments provided, it reaches $\mathrm{X}_{i} \mathrm{M}$ (Exports higher than Imports). Through this assumption that many countries are tempted to open up and conduct international trade and even target the achievement of expansion of exports.

All excess domestic production is expected to be able to be traded abroad and generate profits for the country rather than excess goods. It will only have an impact on excess domestic goods that can make domestic inflation, so the assumption of throwing out goods can have a more significant profit effect for a country. According to the classical assumption theory through Adam Smith's "Absolute Advantage," which emphasizes that free trade will undoubtedly bring an advantage to the trading country.

\section{RESEARCH METHOD}

The type of data used in this study is secondary data in the form of time-series data, and sourced from Bank Indonesia within 15 years, but also obtained from library research, library research, websites related to foreign loans, interest rates, and exports.

Data Collection Methods in this study the authors use library research (Library Research), the research conducted is through library materials in the form of scientific writings, journals, articles, magazines, scientific research reports that are related to the topic being studied. Data collection techniques used are direct recordings in the form of time series data 15 years.

In analyzing the effect of independent variables on the dependent variable, an econometric model is used. The analysis technique used is the ordinary least squares method (Ordinary Least Square or OLS).

The data used were analyzed quantitatively using statistical analysis, namely multiple linear equations. The equation model used is as follows:

$$
e^{Y}=\beta_{0} X \beta_{1} e^{\beta_{2} X_{2}+\beta_{3} X_{3}+\mu}
$$

Then the function is transformed into a linear regression equation model with the following model specifications:

$$
\ln Y=\beta_{0}+\beta_{1} X_{1}+\beta_{2} X_{2}+\beta_{3} X_{3}+\mu
$$

Where:

$\mathrm{Y}$ : foreign exchange reserves (million USD); $\alpha$ : intercept; $\beta_{1}, \beta_{2}, \beta_{3}$ : regression coefficient; $X_{1}$ : overseas loans (million USD); $X_{2}$ : interest rate (percent); $X_{3}$ : export (Million USD); $\mu$ : term of error.

\section{ANALYSIS}

The individual significance test of the variable Foreign Loans in Table 1 is partially positively and significantly related to foreign exchange reserves in Indonesia for the period 2002-2016. Variable Foreign Loan shows the probability value of 0.0000 less than the 5 percent significance (0.05). The regression coefficient of the variable Foreign Loans is 0.30 , meaning that each increase in Foreign Loans by 1 percent results in an increase in foreign exchange reserves by 0.30 percent.

The interest rate variable is partially negatively and negatively related to foreign exchange reserves in Indonesia for the period 2002-2016 because the probability value is 0.4072 , more than the significance of 5 percent, $(0.05)$. Then the export variable has a positive and significant effect on foreign exchange reserves in Indonesia for the period of 2002-2016. Variable export have the probability value of 0.0065 less than the significance of 5 percent, (0.05). The export regression coefficient have 2.51 , meaning that each $1 \%$ increase in exports increases foreign exchange reserves of $2.51 \%$. All variables simultaneously significantly influence foreign exchange reserves in Indonesia for the period 2002-2016. The F statistic probability shows a value of 0.0000 less than the 5 percent significance.

\subsection{The Effect of Foreign Loans on Foreign Exchange Reserve in the Period of 2002-2016}

Research findings from the estimation results indicate that the variable Foreign Loans has a positive and significant effect on foreign exchange reserves, which means that if foreign loans increase, foreign exchange reserves will increase significantly. Foreign loans are one of the macroeconomic variables that describe financial conditions in terms of external financing. As we know, foreign loans are divided into two parts, namely private and government. Foreign loans from year to year are always increasing in nominal terms. These results are consistent with the research hypothesis and previous research, which states that an increase in foreign loans will increase foreign exchange reserves, because basically. Each flow of funds that enters the 
Table 1: Estimated Results of Analysis of Factors Affecting Foreign Reserves in Indonesia

\begin{tabular}{ccccc}
\hline Variable & Coefficient & Std. Error & t-Statistic & Prob. \\
\hline foreignloansX1 & 0.305796 & 0.040092 & 7.627408 & 0.0000 \\
interest & -1275.828 & 1480.370 & -0.861831 & 0.4072 \\
export & 2.515819 & 0.751299 & 3.348627 & 0.0065 \\
C & -5476.002 & 19347.05 & -0.283041 & 0.7824 \\
\hline R-squared & 0.957801 & Mean dependent var & 73952.05 & \\
Adjusted R-squared & 0.946292 & S.D. dependent var & 33995.43 & \\
S.E. of regression & 7878.434 & Akaike info criterion & 21.00482 & \\
Sum squared resid & $6.83 \mathrm{E}+08$ & Schwarz criterion & 21.19364 & \\
Log likelihood & -153.5362 & Hannan-Quinn criter. & 21.00281 & \\
F-statistic & 83.22296 & Durbin-Watson stat & 1.518060 & \\
Prob(F-statistic) & 0.000000 & & & \\
\hline
\end{tabular}

country can increase foreign exchange reserves with these additional funds. However, on the other hand, the country can increase foreign exchange reserves by managing foreign loans to increase exports to increase the country's foreign exchange reserves. The results of this study are in line with the results of previous studies conducted by Adiyadnya 2017 conducted a study that examined the effect of inflation, the US dollar exchange rate, lending rates, and foreign loans on Indonesia's foreign exchange reserves in 1996-2015.

\subsection{The Effect of Interest Rates on Foreign Exchange Reserves in the Period of 2002-2016}

Based on the results of the study, the variable interest rates do not have a significant relationship with foreign exchange reserves. These results are not by the research hypothesis, which states that interest rates have a negative and significant effect on foreign exchange reserves, because every drop in interest rates makes it will encourage increased investment in Indonesia. The increase in investment further affects the increase in aggregate income. The increase in aggregate income can increase the ability of imports; if the import value is higher than the export value, this can cause a deficit in the balance of payments through the trade balance and reduce the position of foreign reserves. It was proven in the last 5 years (2012-2016) the balance of payments in the current account experienced a deficit of $-24,418,-29,115,-27,499,-17,519,-16,952$ million USD.

\subsection{The Effect of Exports on Foreign Exchange Reserves in the Period of 2002-2016}

Export variables have a positive and significant effect on foreign exchange reserves. These results are consistent with the research hypothesis, which states that exports have a positive influence on foreign exchange reserves. When exports increase, foreign exchange reserves also increase which is the result of export sales of goods and services paid using foreign currencies, so it can be said that the foreign exchange from exports has a significant contribution to the economy, in this case, one of which is as a source of additional foreign exchange reserves
Especially because exports accounted for $70 \%$ of Indonesia's total foreign exchange reserves. The results of this study are in line with the results of previous studies conducted by Agustina 2014 and Sayoga and Tan 2017, which states that exports have a positive effect on foreign exchange reserves.

\section{CONCLUSION AND SUGGESTION}

This study aims to determine the effect of foreign loans, interest rates, and exports on foreign exchange reserves in Indonesia during the years 2002-2016. Based on the results of data analysis and discussion can be concluded as follows.

Foreign loans are positively related on foreign exchange reserves in Indonesia for the period 2002-2016. Interest rates are have no effect on foreign exchange reserves in Indonesia for the period 2002-2016. Exports are positively related on foreign exchange reserves in Indonesia for the period 2002-2016. This means that the higher the export will affect the increase in foreign exchange reserves, while the smaller the export will affect the number of foreign exchange reserves Based on the analysis of the influence of several variables, namely foreign loans, interest rates, and exports, some suggestions were put forward, namely the need for short-term foreign loans to increase economic development in Indonesia. Both the government sector and the private sector, but with the required amount.

It is necessary to control precisely the rise and fall of interest rates in Indonesia so that investment and exports in Indonesia can increase, which causes foreign exchange reserves to increase. Increasing the value of exporters in Indonesia using exporting raw materials, it is necessary to process raw materials so that the selling value is high. For all authorized institutions, especially, the government must continue to maintain and enhance the position of foreign exchange reserves in Indonesia. Steps that can be taken by the government include increasing export activities and reducing imports, creating a pleasant investment climate to attract foreign investors to invest their capital, improve and provide training for workers to be more productive and provide capital to small companies and intermediate. These steps can add and improve the position of foreign 
exchange reserves in Indonesia.

\section{References}

Abadi, Adit Fairuz (2014). Analisis Pengaruh Karakteristik Peminjam, Besar Pinjaman, Jenis Usaha, dan Lama Usaha Terhdap Tingkat Kelancaran. Pengembalian Kredit Usaha Rakyat (KUR) Mikro. Fakultas Ekonomika Dan Bisnis Universitas Diponegoro.

Adiyadnya, Made Santana Putra (Feb. 2017). "Analisis Pengaruh Inflasi, Kurs Dollar Amerika Serikat, Suku Bunga Kredit dan Utang Luar Negeri Terhadap Cadangan Devisa Indonesia Tahun 1996-2015”. In: Jurnal Riset Akuntansi 7.1 .

Agustina, Reny (2014). Pengaruh Ekspor, Impor, Nilai Tukar, dan Tingkat Inflasi terhadap Cadangan Devisa Indonesia Tahun 2008-2012. Medan: Program Studi Akuntansi STIE Mikroskil.

Asmanto, Priadi and Sekar Suryandari (2008). Financial Deeping, dan Stabilisasi Nilai Tukar Riil Rupiah Akibat Gejolak Nilai Tukar Perdagangan dalam Cadangan Devisa. Buletin Ekonomi Moneter dan Perbankan Bank Indonesia. Jakarta: Bank Indonesia.

Atmaja, Lukas Setia (2008). Manajemen Keuangan, Buku I. Yogyakarta: Penerbit Andi.
Lipsey, Ragan and Courant (1997). Economics. Jakarta: Erlangga.

Mankiw, N. Gregory (2000). Teori Makroekonomi. Ed. by Imam Nurmawan. 4th. Jakarta: Erlangga.

Meier, M. G. (1995). Leading Issues in Economics Development. International. Singapore: McGraw Hill Finance Series.

Muhammad, Marie (2006). Kebijakan Fiskal di Masa Krisis 1997. Jakarta: Penerbit Buku Kompas.

Nopirin (1998). Ekonomi Moneter. Yogyakarta: BPFE.

Pattillo, Catherine (2002). External Debt and Growth. Finance Development Quarterly Magazine of the IMF.

Prasetiantono, T. A. (2000). Keluar Dari Krisis: Analsis Ekonomi Indonesia. Jakarta: PT.Gramedia Pustaka Utama.

Samuelson, Paul A and William D Nordhaus (1997). Microeconomics. Jakarta: Erlangga.

Sayoga, Pundy and Syamsurijal Tan (Jan. 2017). "Analisis cadangan devisa Indonesia dan faktor-faktor yang mempengaruhinya". In: Jurnal Paradigma Ekonomika 12.

Yustika, Ahmad Erani (2000). Industrialisasi Pinggiran. Yogyakarta: Pustaka Pelajar. 